\title{
Globalisation and the Politics of Persuasion and Coercion
}

\author{
Tom Conley
}

\begin{abstract}
This paper argues that an economic liberal discourse of globalisation has been pivotal to the policy-making process in Australia over the past 15 or so years. Both Labor and Coalition Governments have aimed to restrict the electoral fall-out from the process of restructuring by persuading Australians that the world economy has forced particular policy changes and made alternative economic policy choices unviable. Policy-makers act to influence conceptions of the appropriate role and responsibilities of the state through persuasion - the rhetoric they speak - and coercion - the policies they make. The pervasiveness of globalisation rhetoric in the public sphere has been essential to the governing process as a complement to and buffer for the coercive impact of economic liberal policy changes. As Australia has shifted from a protectionist to an economically liberal policy structure, the effects of globalisation have become clearer. Liberalisation has intensified pressures from the world political economy and coerced changes in all areas of policy and the economy, as well as in public perceptions about the 'limits of government'. Globalisation and economic liberalism as persuasion and coercion are the component parts of a restructured system of political and economic governance: a paradigmatic shift away from the economic protectionism of the first 80 years of Australian federalism.
\end{abstract}

Dr Tom Conley

Tom Conley lectures in international relations and political economy at Griffith University. His major research interests are the impact of globalisation on domestic politics and policy, and the politics of economic policy.

T.Conley@griffith.edu.au 


\section{Introduction}

We must let Australians know truthfully, honestly, earnestly, just what sort of international hole Australia is in. It's the price of our commodities - they are as bad in real terms since the Depression ... and if we don't make it this time we never will make it. If this government cannot get the adjustment, get manufacturing going again and keep moderate wage outcomes and a sensible economic policy, then Australia is basically done for. We will just end up being a third-rate economy ... If in the final analysis Australia is so undisciplined, so disinterested in its salvation and its economic well being, that it doesn't deal with these fundamental problems, then the fallback solution is inevitable because you can't fund $\$ 12$ billion a year in perpetuity every year ... the only thing to do is to slow the growth down to a canter. Once you slow the growth under 3 per cent, unemployment starts to rise... Then you are gone. You are a banana republic. (Paul Keating in 1986 cited in Kelly 1994: 212)

In a National Press Club Speech in the lead up to the 1996 election, Paul Keating argued that Australians did not want another salesman as their Prime Minister. The irony was overwhelming. Here was one of Australia's greatest-ever political salesmen, responsible for selling Labor's enormous policy changes of the 1980s and 1990s, suggesting that an ability to sell policy was neither necessary nor desirable. The ability to sell changes - to persuade - is vital to the making of policy, especially during a period of economic turmoil and restructuring. Economic matters have dominated public policy debates in Australia over the last two decades. Management of the economy, however, is only one of the tasks faced by a government. Just as important is the maintenance of an electoral coalition sufficient to ensure re-election. Whilst effective economic management is an important part of maintaining electoral support, economic liberal policy changes deemed essential to cope with globalisation have had negative consequences for large sections of the population (Pusey 2003; Saunders 2003; Smeeding 2002, Krugman 2002; Harding, Lloyd and Greenwell 2001). Efforts to sell policy change, therefore, have involved both preparation and justification.

The shift to economic liberalism in Australia has been seen variously: as the dominance of a particular set of ideas (Whitwell 1994; Pusey 1991; Stretton 1987: 202-207), as in the longer-term interests of capital (McEachern 1991), as signalling changes in Australian society (Muetzelfeldt 1992), as a result of particular state responses to contingent crises (Walsh 1991), and as an international imperative, forcing domestic adjustment (Kelly 1994, Catley 1996, Bryan and Rafferty 1999). This last explanation has become the dominant interpretation of, and justification for, the shift to economic liberalism. Policy-makers have used globalisation to sell economic liberal policies to an often sceptical and concerned public. Both Labor and Coalition Governments have aimed to restrict the electoral fall-out from the process of restructuring by persuading Australians that the world economy has forced particular policy changes and made alternative economic policy choices unviable. With support and assistance from a loose coalition of supporters of globalisation and economic liberalism in business, the bureaucracy, the academy and the media, policy-makers have continually sold the message that globalisation limits what the political process can achieve. Increasing resort to market 
mechanisms and a limited role for government have been argued to be both integral to the reinvigoration of economic growth and unavoidable because of globalisation.

In a liberal democracy, authority and legitimacy are passed from an electorate to a government, which then must deal with governing an economy and society. How the governing process is normalised is vital: the expectations that populations have of the state will affect the ease or difficulty of governing and the extent to which governments are held responsible for economic developments and outcomes. Governments and the wider state apparatus act to influence such conceptions through persuasion - the rhetoric they speak - and coercion - the policies they make. ${ }^{1}$ The pervasiveness of globalisation rhetoric in the public sphere has been essential to the governing process as a complement to and buffer for the coercive impact of economic liberal policy changes. As Australia has shifted from a protectionist to an economically liberal policy structure, the impacts of globalisation have become clearer. Liberalisation has intensified pressures from the world political economy and coerced changes in all areas of policy and the economy, as well as in public perceptions about the "limits of government". Globalisation and economic liberalism as persuasion and coercion are the component parts of a restructured system of political and economic governance: a paradigmatic shift away from the protectionist policy structure of the first 80 years of Australian federalism (Conley 2001a).

This paper contends that the discourse and practice of globalisation have fundamental implications for politics in Australia and other democracies throughout the world. Unless challenged, this pessimistic view of the possibilities of politics could lead to a self-fulfilling prophecy of policy impotence.

\section{Ideological and Material Components of Globalisation}

The world is out there, but descriptions of the world are not (Richard Rorty cited in McCloskey 1994: 200).

In recent years, globalisation has been increasingly used as a shorthand term to express the impact of the wider world on the nation-state. Globalisation and other terms of external constraint such as internationalisation, interdependence, and integration have provided neat rhetorical devices for governments and commentators throughout the world to convey the idea that economic liberal adjustment is the only viable policy strategy. In Australia, these global references have been used to explain that the days of Australia as a lucky country, prosperous despite itself, are gone (Horne 1964). Conceptions of economic globalisation have been used to support the argument that Australia's long-standing "protectionist" policy structure had to be dismantled and that egalitarian aims are unviable. Deterministic constructions of the effects of the world political economy from a wide range of political viewpoints have underpinned the claim that previous economic and political practices, lifestyles and expectations must be adjusted to take into account new global "realities".

Despite much academic criticism of deterministic assessments of globalisation (Conley 2002; Rosamond 2003; Hay and Watson 2003), it is evident that many policy-makers, economic elites and analysts believe that globalisation is an inevitable and irreversible process that compels states to embrace economic liberal policies (Conley 1999, 2001b). 
Political rhetoric and policy decisions throughout the developed world in recent years have worked together to lower expectations about what is politically possible in a globalising world economy (Hirst and Thompson 1996; Cerny 1996). The discourse of globalisation has had a crucial effect on the development of globalisation and hence on the way different people experience it. As Robertson (1992: 61) puts it: 'conceptions of the world system, including symbolic responses to and interpretations of globalization, are themselves important features in determining the trajectories of that very process' (See also Robertson and Khondker 1997).

Such a contention implores us to take ideas, rhetoric and discourses seriously. Although fundamental policy changes cannot be understood solely or even mainly in terms of the changing ideas of policy-makers, economic liberal ideas combined with a growing discourse of external constraint provide a powerful framework to guide a reform-minded government. As Rose (1993: 3) points out, we need to be aware of 'the fundamental role that knowledges play in rendering aspects of existence thinkable and calculable, and amenable to deliberated and planful initiatives'. Perceptions of the world and actions based on them are fundamental to the shaping of social, political and economic developments. Authoritative pronouncements and comprehensive efforts to persuade have important impacts in and of themselves, but dominant interpretations can also act in a self-fulfilling way, as policy decisions based on such interpretations transform policy structures and coerce adaptation. Invoking global imperatives may, for some policy-makers, be an attempt to persuade populations of what they see as the "reality" of globalisation and does not necessarily involve a cynical manoeuvre to fool the public. At the same time, however, the construction of globalisation as a policy imperative requiring economic liberalism constitutes more than just a theory that attempts to make sense of the world (Youngs 1996). It is also a claim with political intent that advantages particular coalitions of interests. A singular and simplistic understanding of globalisation has been used for the political purpose of educating populations about overarching global constraints and to marginalise alternative views that could be used to justify different policy directions and goals.

Ideological components of globalisation need to be considered together with material ones. These material components involve the interplay between global and domestic structures and interests. In the case of Australia, this involves interplay between the Australian political economy and the global political economy. In the early 1980s, it became increasingly clear that Australia was beset by a number of structural problems. On the economic side, Australia was too reliant on commodity exports, which were declining in relative value, had an uncompetitive manufacturing sector and a low level of exports generally. On the political side, Australians had come to expect governments to maintain the protective policy structure (Conley 1999: ch. 4; Castles 1988). It was also obvious that the global political economy was changing as well. The collapse of Bretton Woods, stagflationary crises in the advanced capitalist world and the rise of East Asia contributed to the perception that policy structures had to change. Economic policy changes, in turn, contributed to further globalisation, which created new pressures for policy change and for reorientation of business strategies. It needs to be restated here that the aim to elevate ideas, rhetoric and discourse is not to downplay the importance of material constraints. The aim, rather, is to note that at each point of material change, ideas play a constitutive role in interpreting material reality and in deciding courses of 
action. Most importantly, the discourse of globalisation and the rhetoric of no alternative to economic liberalism are important because dominant ideas become institutionalised through economic policy choices.

Labor under Hawke and Keating believed that Australia's structural problems in a globalising world required substantive policy and attitudinal changes. Labor was influenced by an understanding of globalisation that posited limited choices if countries were to generate economic growth. Integral to the project of change in Australia, therefore, was a utilisation of a widespread and growing discourse of external constraint that increasingly became subsumed under the label of globalisation. Labor's rhetoric of globalisation (Conley 2001b) differed from that of the Liberal-National Coalition in Opposition, which argued for a more rapid and comprehensive change to the policy structure. Labor, however, had to construct a different coalition of interests than the Coalition would have, had it been in office. Part of Labor's task was to persuade much of its support base that there were limited options available if Australia were to generate the growth necessary to underpin improving living standards. The task for the Coalition in government is different because the material structure has changed and because they have to appeal to different constituencies. Labor substantially transformed the political economy in the 1980s and early 1990s and the task for the Coalition has been about consolidating economic liberal globalisation in the face of vocal opponents of the changes. Persuasion continues to be an essential component of governing.

The discourse of constraint has been operationalised to overcome another prominent discourse in advanced capitalist nations, that of political choice, the fundamental tenet of democracy. Governments have not yet been able to extricate themselves from managing the deleterious effects of market processes, but through efforts at public persuasion and through coercive policy changes, policy-makers have worked on reversing expectations that the state's protective and redistributive functions will continue to expand. As Ikenberry (1995: 121) contends, the advanced capitalist states have 'tried to reduce the public's expectations about what national governments are responsible for doing and achieving. The idea is to "shed" some of the state's perceived responsibility for social and economic well-being, and thereby remove it as an object of blame'.

\section{Globalisation as Persuasion}

The post-war period in the developed world was an era of sustained growth and expanding public expectations about the role of the state in underpinning continuing improvements in living standards. States took greater responsibility for economic outcomes and took much of the credit for the successes of the "mixed economy". Growing economic malaise in the 1970s, however, severely impeded the momentum of state expansion, reduced policy optimism and led to a reassessment of assertions about appropriate roles and tasks for the state (Brittan 1975; Gourevitch 1986).

Despite its free market rhetoric and attacks on "big government", the Fraser Government's (1975-83) response to economic difficulties fitted well within the prevailing protectionist policy structure. Contrary to later assertions of policy powerlessness in the face of immutable economic forces, Fraser stressed that governments were unequivocally in charge of economic affairs: 
I do not believe that men and women are governed by inexorable events beyond their control. When political leaders say the present situation cannot be helped, it is part of a world situation, they are expressing the futility of their own leadership when, if they were men of real stature, they would be saying "We can overcome" (Malcolm Fraser cited in Kelly 1984: 424-5).

Fraser did not attempt to change the long-standing view that the state would continue to protect Australian economic actors during times of economic difficulty. In response to Whitlam's 25 per cent across-the-board tariff cut, Fraser stated: 'We will give Australian industry the protection it needs. We would sooner have jobs than dogma' (cited in Warhurst and Stewart 1989: 164). He also encouraged Australians to believe that natural resources would continue to underpin prosperity. This faith in resource abundance, Bob Hawke (1985b) later argued, led to false and exaggerated hopes and to squandered opportunities.

From its very first days in office, the Hawke Labor Government stressed the impediments to social reform and the need for changing expectations about the role of the state. Hawke's initial framework for the reshaping of attitudes was built around the notion of "consensus", which alleged that compromise and cooperation between Government, the unions and business was the most effective way to reinvigorate the Australian economy (Hawke 1983a: 508). Hawke (1983b: 1627) urged Australians to get used to the fact that the 'years' of the fifties, sixties and early seventies were 'behind us'. Treasurer Paul Keating (1983: 1828) reinforced this view, opining that:

the experience of the past ten years has essentially been one in which Australians have had to adjust their expectations in the face of a diminished economic performance. We have had to recognise and give greater attention to the economic limits on programs of reform.

Australia could no longer rely on commodity wealth or resource booms and Keating (1983: 1828) insisted that the ability of government to provide 'an ever expanding standard of living' had been 'heavily circumscribed'.

The Labor Government continually made the public aware of the difficulties that policy-makers were facing and argued that economic circumstances required not only sacrifice, but understanding that the state could not be held responsible for economic problems when their causes lay in changes in the world political economy. This was particularly the case with the economic crisis of 1986, which provided opportunities for the Government to push through difficult policy changes (for accounts of these events see Edwards 1996; Kelly 1994). The extent to which the crisis was seen as an opportunity is evident in Keating's unhappiness that Australia's terms of trade - the underlying cause of the crisis - had improved by the late 1980s:

What was disappointing for me was having just won an election in July 1987 on an austerity mandate, yet almost from the time the election was over, the terms of trade started to lift and we got to the point where we couldn't use the mandate (Keating cited in Duffy 1990: 15).

Crisis generated a constituency for change and allowed the Labor Government to push through policies that would have been difficult to justify in more benign economic times. 
Over the longer term, however, Keating (cited in ibid.) argued that avoiding adjustment was not an option:

So when people attack the government for running too firm a monetary policy, too firm a demand management policy, they've got to understand that this place is going to get adjusted one way or another. And it'll get adjusted, if later, in a more catastrophic way, or earlier in a more sympathetic way.

The resulting policy-induced recession illustrates the danger of a penchant for austerity and forced adjustment.

Attitudinal change has been a major theme of policy-makers and other supporters of economic liberalism and globalisation in recent years. As Prime Minister, Keating (1993) continued to pushed the theme of cultural adaptation:

We cannot expect to change the direction of our trade and commerce, adapt to the revolutionary changes in the processes of production and the nature of work and to the equally radical changes in the global economy without cultural change.

The constant stress on attitudinal or cultural adjustment intimates that, although the role of government is important in encouraging and facilitating change, the "real solution" to the problems thrown up by "new global economic realities" lies with Australian economic actors and the wider community. As Hawke (1988) put it: 'Australia's growing enmeshment with the world economy requires that change becomes increasingly accepted as part of virtually every aspect of our lives'. Such exhortation has generally been framed in attractive terms, but not always. Keating (cited in Ellis \& Shires 1995: 1) argued ominously that the process of adaptation to the world economy did not have an endpoint: global economic competition was like 'a long-distance race - a very long distance race...Like the modern marathon it gets faster and faster. But unlike the marathon it has no finish line'.

By the mid-1990s, after considerable state retrenchment and constant efforts to lower expectations, it seemed to be an electoral virtue not to promise too much (Megalogenis 1995: 4; Hughes 1996: 2). The aim was to restore faith in government by lowering expectations. The Coalition went to the 1996 election with a modest and moderate programme that was designed to exorcise the demon of John Hewson's Fightback! manifesto. The Howard Government, however, has continued the rhetoric about the need for constant adaptation. Despite his assertion that most people 'prefer stability to change', Howard (1997) argued that '[ $t$ ]he difficult fact that has to be faced is that the correct response to globalisation is more liberalisation not less. More change, not less. More willingness to embrace new ideas, not less'.

Howard (2001) has also been keen to continue with the theme that globalisation is both inevitable and irreversible and that people had better get used to it:

[T] he world has indeed changed forever and any notion that the changed world can be turned back, any notion that somehow or other we can shrink away into a corner and ignore the globalised environment in which we exist is completely ill founded. Our challenge is not to avoid or resist globalisation. 
Overall, the emphasis is on the futility of resistance to globalisation. Treasurer, Peter Costello (2001), sums up this argument by stressing that:

[G]lobalisation is not a value, it is a process. Globalisation describes what is happening. And ranting against globalisation is like ranting against the telephone...And what is more, you will not reverse this process.

Howard qualifies his argument, in a fashion similar to that of his Labor predecessors, by acknowledging that government needs to play a limited role in the adjustment process. A particularly important role for government is to educate the public about the benefits of economic liberal globalisation. In 1996, Howard ordered all economic policy departments to compile evidence of the gains to Australia from tariff liberalisation (Henderson 1996: 4). In 1997, the Government put out a White Paper entitled In the National Interest (DFAT 1997a) and another document entitled Trade Liberalisation: Opportunities for Australia (DFAT 1997b). The latter document, along with another entitled Foreign Direct Investment: The Benefits for Australia (DFAT 1999), were aimed at making the case for freer trade and investment in the face of noisy protests and growing community concerns about the impact of globalisation. The Government has also released packages for the community and schools outlining the benefits of globalisation (McKenzie 1997: 34). In 2001, the Government released another document called Exploding the Myths: Facts About Trade and Investment (DFAT 2001a), which attempts to counter views such as the belief that tariffs protect jobs (ironically, a position that Howard had resorted to in the tariff debates in 1997). A defence of APEC's trade liberalisation agenda, Open Economies Delivering to People: APEC's Decade of Progress (APEC Secretariat 2000), was accompanied the following year by a document for use in schools entitled Investigating Globalisation through the APEC Experience (DFAT 2001b). The argument that the developing world benefited unequivocally from globalisation was set out in Globalisation and Poverty: Turning the Corner, a publication of the Centre for International Economics assisted by the Department of Foreign Affairs and Trade (DFAT), the Australian Agency for International Development and Treasury. In 2003, the Government still thought it necessary to reinforce the message about the benefits of globalisation in a publication entitled Globalisation: Keeping the Gains written by the Economic Analytical Unit of DFAT (EAU 2003).

The argument of supporters of economic liberalism is that if the community is informed about the benefits of globalisation, then they will come around to supporting it. As Howard (2000a; see also 2002) contends:

At this pivotal point in the development of the world economy, the greatest challenge for governments must be to communicate the benefits of globalisation to their citizens ... In short, my message is that globalisation, both as a concept and in practice, must be nurtured by governments and businesses...

Bureaucratic policy-makers have also spent considerable time attempting to educate the public, business and their political masters about the benefits of globalisation and economic reform. Reserve Bank Governor, Ian McFarlane (cited in Dwyer 1998: 10), for example, urged the Howard Government to maintain its resolve in the face of Hansonism and continue with microeconomic reform. Governments, he argued, 
needed to 'explain to the general public the benefits which flow from these changes'. Governments have also had considerable backing in the public education campaign from the business sector. Some commentators have argued that such educative efforts need to be more widespread. As one noted: 'given that the broad substance of reformist economic policies can't sensibly be challenged, explaining their rationale must be improved' (Grattan 1998: 19). The problem with these assertions is that over the past 15 years policy-makers have constantly expended energy on persuading people that globalisation is good for them.

The Howard Government has also extended earlier themes of a limited role for government. In the early days of office, Howard (cited in Gordon 1997: 6) was keen to downplay expectations in areas such as unemployment: 'we are living in a society of very big change. A government has got certain powers, but in a globalised economy even the Governments of the United States and Japan, the two greatest economies in the world there are limits to what they can achieve too'. The overriding themes are policy modesty and greater individual self-reliance. Howard (cited in Shanahan 1998: 7) argues that Australia 'needs a new style of government, one which acts strongly within the realms of the possible, one with a disposition towards individuals finding their own solutions... Only in this way will we have the strength to face the future, to face the challenges of globalisation'. Treasurer Costello also stresses the 'limits of government':

If you limit government to what it can do, it is likely to do that better, and likely to do less damage than if it intervenes in areas where it has no competence...I think there has been a tendency for government to encourage the belief that it can solve any kind of problem. This inevitably leads to disappointment...I have always been a believer in limited government (cited in Henderson 2001).

Constructions of the imperatives of globalisation have provided support for the argument that the state should, wherever possible, give way to market processes. This was a theme begun in earnest from the earliest days of the Hawke Government. Market failures were downplayed and policy failures reassessed as unfortunate but inevitable outcomes of (global) forces beyond Australia's control. The failure of 1980s economic theories such as the "J-curve" and the "twin deficits" to deliver promised results was, in the final analysis, ignored because the economic liberal policy changes they supported were seen as either beneficial or inevitable over the longer term anyway.

Attempts to persuade and educate Australians that limited government and economic liberalism are most appropriate for a global era are, however, only one side of the story. Persuasive efforts have been given substance through the coercive effects of policy change.

\section{Economic Liberal Coercion}

Undoubtedly pressures from the world political economy would have had a substantial impact on Australia over the past 20-30 years with or without policy change. The breakdown of the Bretton Woods financial order; financial liberalisation in other countries; the ever-increasing push by investors and speculators to buy and sell currencies, bonds, stocks and an expanding array of financial derivatives; the search for 
profits beyond national borders by multinational companies; and improvements in the technologies of transportation, communication and information - all were occurring regardless of what happened in Australia. Australia is a minor player in a changing world political economy. But this does not mean that the way the Australian political economy is regulated is inconsequential. Both external and internal regulations shape the effects of the world political economy and the ways different economic actors, groups and individuals in society experience globalisation. Regulation and state institutions shape the pace of change and, most importantly, the distribution of adjustment costs and benefits. In short, globalisation has impact through the prism of Australia's policy structure.

While rhetoric about the imperatives of globalisation has pervaded public debate, provided support for policy change and helped to marginalise alternative policies, it has been the economic liberal policy changes themselves that have accentuated the effects of the world political economy and coerced changing assessments of the role of the state and the need for continual market adjustment. The shift in policy direction away from the protectionist policy structure has increasingly placed the onus of adjustment onto domestic economic actors and the wider population and has been pivotal to the "education" of Australians about globalisation. By reducing the regulatory barriers that had in the past helped to insulate Australia, economic liberal change has made the effects of globalisation more direct and obvious, strengthening, in a self-fulfilling way, claims about global "imperatives". This, indeed, has been the very aim of policy (Conley 2002).

Through the combined effects of globalisation and economic liberalism, Australia has been increasingly exposed to the coercive impact of global finance, investment and trade. Financial liberalisation has made the effects of finance more obvious, increasing the scope and speed of financial market actors to judge economic policy and pressuring governments to structure policy to avoid adverse financial reactions. The liberalisation of exchange controls has meant that capital can more easily flow out of an economy if policies are considered unfavourable to business and finance (Conley 1996). The huge build-up of foreign debt has increased Australia's vulnerability to changing international financial sentiment. The liberalisation of trade has increased the competitive pressures of a world trading system still structured by political intervention and oligopoly. While it is the ideal of free trade to which economic liberals refer, it is a world political economy to which economic actors and populations have to adjust. The growth of international production strategies, the relaxation of regulations and efforts to attract and retain investment intensify pressures on both economic actors and government.

Increased competition has had a number of effects: it has pressured business to increase productivity, unions to restrict wage claims and industrial disputation, and governments to lower business costs and to push the pace of microeconomic reform. Each economic liberal policy response has reinforced the already substantive constraints of the world political economy and pushed policy-makers to extend reform to other sectors of the economy. Domestic liberalisation worked to enforce the adjustment of those sectors of the economy not directly involved in, or exposed to, trade. Unregulated capital flows and macroeconomic policy rigidity did not help the current account problem and in the early 1990s led to the ultimate discipline on the domestic economy - a policy-induced recession 'we had to have' (Keating 1990: 1). Financial discipline is now taken as a given 
and continues silently to shape perceptions of fiscal possibilities. Policy-makers and economic actors have had to get used to large swings in the value of currencies and substantial current account deficits seem to have been accepted as a normal state of affairs. The burden of wide swings in the value of the dollar is now borne by business rather than by government policy.

Globalisation, liberalisation, privatisation and the general marketisation of economic relations mean that market forces are now more important in determining socio-economic outcomes. The marginalisation of notions of economic and social protection, the celebration of continual economic adjustment, and the reinforcement of these ideas through policy changes, have encouraged and coerced citizens to think of themselves as economic actors, succeeding and failing on market terms. As Rose (1996: 340) argues, the very notion of government has been 'restructured according to a particular image of the economic - the market'. The increased coercion of market forces unleashed by regulatory change has also enabled policy-makers to argue that they are less responsible for economic outcomes. As Keating (cited in Wallace 1994: 20) insisted:

Just look at the old system, the people who believed in high tariffs, the people who believed in a regulated financial system - the new markets took them out. We didn't take them out - the markets took them out.

Policy-makers have expended considerable effort persuading business and workers that there was no future in protection and then, by lowering tariffs, coerced them into accepting the "new reality". In industrial relations, Keating (cited in ibid.) claimed that the shift to enterprise bargaining lessened the Government's responsibility for outcomes: 'The Government doesn't take the rap because this is a system where it's all up to the participants'.

Through economic liberalism, the state and other important societal actors have aimed to limit the direct role of government and to enhance what Miller and Rose (1990) call 'government at a distance' - the fostering of the self-regulating ability of individuals and populations. The aim of globalisation as persuasion and coercion has not just been to change a whole range of protective regulations but to change the way that society is governed and, indeed, the way that the individuals that make up Australian society govern themselves. As John Howard (2000b) argues:

We believe as we always have that "the only real freedom is a brave acceptance of unclouded individual responsibility". And in making policy since we took office, that encouragement of self reliance, of giving people choice, of rewarding those who can and do take responsibility for themselves and their families has been at the forefront of our efforts.

Economic liberalism governs through the notion of economic choice, with markets constructed as a new "democratic" forum for the processing of preferences. A good example is provided by the construction of Australia as a "shareholder's democracy". Political choice, meanwhile, is marginalised by the pervasiveness of the economic liberal discourse of globalisation and the self-reinforcing nature of the economic liberal policy structure, which increases the power of global economic actors to threaten and punish alternative policy programmes. 
The shift towards economic liberalism has increased market power and has been most advantageous to those groups in society best able to take advantage of global opportunities. Globally-focused business, the wealthy, and highly-skilled labour have all benefited from economic liberal globalisation. Increased regulatory "flexibility" allows greater opportunities to exploit and to shift adjustment pressures onto those with less market power (unskilled workers, the unemployed and the poor). A reduced public sector and a decline in the state's redistributive role mean that economic growth and improvements in employment and wealth distribution are more reliant on the decisions of private economic actors.

Kelly (2000: 226) argues that the 1993 election signalled that the people had begun 'to reclaim the economic agenda' and 'terminate the imposition of "top down" economic reformism'. While it is true that policy-makers became more aware of the backlash against reform, it is also true that the new policy structure was coercing a change in attitudes and a reassessment about the economy and the policy process. While Howard has been heavily criticised by economic liberals for not accelerating the liberal agenda, he has worked effectively at consolidating the changes in the face of often-vocal criticism. The Howard Government has won over many of those disillusioned with economic policy by successfully diverting attention to other issues such as refugees/asylum seekers and criticism of the so-called politically correct "elites". Pushing its stance on asylum-seekers, border protection, the "war on terrorism", and security issues in general has undoubtedly helped the Coalition to consolidate its support among many traditional Labor voters - the so-called "battlers".

Although the idea of political choice has been challenged and state functions have changed, the role of government has not been diminished. Economic and political restructuring has been a state-led project with a commonality of purpose between bureaucratic and political policy-makers. As Polanyi (1957) pointed out long ago, economic liberalism requires a strong state to enforce the market against demands for social protection. With an economic liberal policy structure, the state must continue to "protect" the market from "spontaneous" demands for political action to shape or replace market outcomes. Efforts by government to ameliorate the worst of market outcomes have helped to manage opposition to globalisation. But, as the economic liberal transformation has proceeded, policy-makers have insisted that the room for state initiative and redistribution is increasingly circumscribed, most particularly by the possibility of negative financial reactions and the requirements of global economic competition. 


\section{Conclusion}

This paper has argued that we need to take ideas, rhetoric and discourse seriously. The contention has been that a discourse of economic liberal globalisation has profoundly influenced policy in Australia in recent years and that governments have utilised rhetoric to persuade Australians that there are no alternatives to the continuous adoption of economic liberal policies. Through persuasion - the rhetoric of globalisation - and coercion - economic liberal policy change, the state under Labor and Coalition governments has broken down Australia's historical protectionist policy framework and strengthened the ability of the world political economy and the market to regulate the allocation of resources, socio-economic outcomes and policy possibilities. In other words, policy-makers have aimed to persuade Australians that they need to adjust to the world political economy and then, through economic liberal policies, they have ensured that such adjustments would occur.

To understand globalisation and its impacts, it is necessary to consider the ideological components of globalisation alongside more traditional concerns about its material structures. Most important is the idea that dominant discourses and understandings based on them shape material structures. Influential conceptions about constraints and opportunities shape ideas about policy, and policy ideas, once implemented, become policy structures. Although persuasion continues to be necessary once economic liberal policy decisions have been enacted, the policy shift alters the structural context within which future economic policy choices must be made and hence coerces changing perceptions of reality and the realms of possibility. In the interplay between the global political economy and the Australian political economy, there is considerable room for different interpretations. Undoubtedly, however, economic liberal globalisation has dominated the perceptions of those who have made the decisions.

One of the most important aspects of globalisation as persuasion and coercion has been the establishment of a culture of diminished expectations about the possibilities of political action. The belief that attempting to alter inequitable market outcomes is not possible in a globalised economy, or that it will actually be counterproductive, helps to ensure that such outcomes do not eventuate. The fostering of the view that economic outcomes are, to a greater extent than ever before, the result of global market forces over which governments have little control, changes the way issues of redistribution are considered: redistribution can only be a marginal phenomenon in an economic liberal, globalised political economy.

Despite the considerable efforts to persuade and marginalise opponents of economic liberal globalisation, differences in the effects of globalisation provide the continuing possibility that interpretative certainties will eventually come unstuck. Some sort of domestic adjustment is always necessary for a small country like Australia, but economic liberalism is not the only form of adjustment available. A social democratic globalisation strategy that eschews polarisation and creates more widely distributed benefits is still possible. 


\section{References}

APEC Secretariat (2000) Open Economies Delivering to People: APEC's Decade of Progress, Singapore.

Billig, M. (1989) 'Conservatism and the Rhetoric of Rhetoric', Economy and Society, $18(2)$.

Brittan, S. (1975) 'The Economic Contradictions of Democracy', British Journal of Political Science, 5(2).

Bryan, D. and M. Rafferty (1999) The Global Economy in Australia: Global Integration and National Economic Policy, Sydney, Allen \& Unwin.

Castles, F. (1988) Australian Public Policy and Economic Vulnerability, Sydney, Allen \& Unwin.

Catley, B. (1996) Globalising Australian Capitalism, Melbourne, Cambridge University Press.

Cerny, P. (1996) 'Globalization and Other Stories: The Search for a New Paradigm in International Relations', International Journal, 51.

Conley, T. (1996) 'The Politics of International Finance', Flinders Journal of History and Politics, 18.

Conley, T. (1999) Economic Discipline and Global Punishment: Globalisation and Australian Economic Policy during the Hawke and Keating Years, Unpublished $\mathrm{PhD}$ Dissertation, Department of Politics, University of Adelaide, Adelaide, June.

Conley, T. (2001a) 'The Re-Globalisation of the Australian Economy', Policy, Organisation and Society, 20(2).

Conley, T. (2001b) 'The Domestic Politics of Globalisation', Australian Journal of Political Science, 36(2).

Conley, T. (2002) 'Globalisation as Constraint and Opportunity: The Restructuring of the Australian Political Economy', Global Society, 16(4).

Costello, P. (2001) 'Challenges and Benefits of Globalisation', Address to the Sydney Institute, Sydney, 25 July.

DFAT (Department of Foreign Affairs and Trade) (1997a) In the National Interest: Australia's Foreign and Trade Policy, Canberra: Commonwealth of Australia.

DFAT (1997b) Trade Liberalisation: Opportunities for Australia, Canberra: Commonwealth of Australia.

DFAT (1999) Foreign Direct Investment: The Benefts for Australia, Canberra, Commonwealth of Australia.

DFAT (2001a) Exploding the Myths: Facts About Trade and Investment, Canberra, Commonwealth of Australia.

DFAT (2001b) Investigating Globalisation Through the APEC Experience, Canberra, DFAT and Ryebuck Media. 
Duffy, M. (1990) 'Three More Hard Years - Or Catastrophe (Interview with Paul Keating)', Independent Monthly, October.

Dwyer, M. (1998) 'Press on with Change RBA Urges Canberra', Australian Financial Review, 3 July.

EAU (Economic Analytical Unit) (2003) Globalisation: Keeping the Gains, Canberra, Commonwealth of Australia.

Edwards, J. (1996) Keating: The Inside Story, Melbourne, Penguin.

Ellis S. \& D. Shires (1995) 'Business Gets Bullish', Australian Financial Review, 25 August.

Gordon, M. (1997) 'Howard's Mantra in Mob Conversion', Australian, 1-2 March.

Gourevitch, P. (1986) Politics in Hard Times: Comparative Responses to International Economic Crises, Ithaca, Cornell University Press.

Grattan, M. (1998) 'How to Overturn the One Nation Bandwagon', Australian Financial Review, 15 June.

Harding, A., R. Lloyd and H. Greenwell (2001) Financial Disadvantage in Australia 1990-2000: The Persistence of Poverty in a Decade of Growth, Smith Family/ NATSEM.

Hawke, R. (1983a) 'National Economic Summit Communiqué', (14 April 1983), Commonwealth Record, 18-24 April.

Hawke, R. (1983b) 'John Curtin Memorial Lecture', (28 September 1983), Commonwealth Record, 26 September-2 October.

Hawke, R. (1985b) 'Inaugural “The Light on the Hill” Lecture', (21 September 1985), Commonwealth Record, 16-22 September.

Hawke, R. (1987) 'Speech at World Economic Forum Symposium', (29 January 1987), Commonwealth Record, 26 January-1 February.

Hawke, R. (1988) 'Speech by the Prime Minister to the Business Council of Australia', Sydney, 11 October.

Hawke, R. (1991) Building a Competitive Australia, Canberra, AGPS.

Henderson, I. (1996) 'PM to Push Tariff Reform Success Stories', Australian, 4 December.

Henderson, I. (2001) 'Costello Launches a Less-Is-More Agenda', Australian, 16 August.

Hirst, P. \& G. Thompson, (1996) Globalization in Question: The International Economy and the Possibilities of Governance, Cambridge, Polity Press.

Horne, D. (1964) The Lucky Country: Australia in the Sixties, Melbourne, Penguin.

Howard, J. (1997) 'Address to Commonwealth Business Forum', London, 23 October 1997 (available at www.pm.gov.au). 
Howard, J. (1999) 'Address at the Australian Industry Group National Dinner', Canberra, 29 March (available at www.pm.gov.au).

Howard, J. (2000a) 'Address at the World Economic Forum', Melbourne, 11 September (available at www.pm.gov.au).

Howard (2000b) 'Melbourne Press Club Address', Melbourne, 22 November (available at www.pm.gov.au).

Howard, J. (2001) 'Address at the Australian Industry Group Dinner', Canberra, 7 August (available at www.pm.gov.au).

Howard, J. (2002) 'Statements at the World Economic Forum', New York, 1 February (available at www.pm.gov.au).

Hughes, J. (1996) 'Court Raises Spectre of WA Inc in Poll Launch', Australian, 2 December.

Ikenberry, G. (1995) 'Funk de Siècle: Impasses of Western Industrial Society at Century's End', Millennium, 24(1).

Keating, P. (1983) 'Inaugural E. G. Whitlam Lecture’, (28 October 1983), Commonwealth Record, 24-30 October.

Keating, P. (1988) 'Address to the Asia Society and American/Australian Society, New York', 4 October.

Keating, P. (1990) 'Statement by the Treasurer: September Quarter Accounts', 29 November.

Keating, P. (1993) 'Address by the Prime Minister, National Press Club, Canberra', 22 July.

Kelly, P. (1984) The Hawke Ascendancy, Revised Edition, Sydney, Angus \& Robertson.

Kelly, P. (1994) The End of Certainty, Second Edition, Sydney, Allen \& Unwin.

Kelly, P. (2000) 'The Politics of Economic Change in the 1980s and 1990s' in D. Gruen and S. Shrestha (eds) The Australian Economy in the 1990s, Reserve Bank of Australia, Sydney.

Krugman, P. 'For Richer' New York Times, 20 October (www.nytimes.com).

Lasch, C. (1995) The Revolt of the Elites and the Betrayal of Democracy, New York, W. W. Norton.

McCloskey, D. (1994) Knowledge and Persuasion in Economics, New York, Cambridge University Press.

Megalogenis, G. (1995) ‘No Big Election Promises: Howard Warns Voters’, Australian, 17 October.

Miller, P. \& N. Rose, (1990) 'Governing Economic Life', Economy and Society, 19(1).

McEachern, D. (1991) Business Mates: The Power and Politics of the Hawke Era, Sydney, Prentice Hall. 
McKenzie, D. (1997) 'The Great Trade-Off', Australian, 13 November.

Muetzelfeldt, M. (1992) 'Economic Rationalism in its Social Context' in M. Muetzelfeldt (ed), Society, State and Politics in Australia, Sydney, Pluto Press, 1992

Polanyi, K. (1957[1944]) The Great Transformation: The Political and Economic Origins of Our Time, Boston, Beacon Press.

Pusey, M. (1991) Economic Rationalism in Canberra: A Nation Building State Changes its Mind, Melbourne, Cambridge University Press.

Pusey, M. (2003) The Experience of Middle Australia: The Dark Side of Economic Reform, Melbourne, Cambridge University Press.

Reich, R. (1992) The Work of Nations: Preparing Ourselves for 21st Century Capitalism, New York, Vintage Books.

Robertson, R. (1992) Globalization, London, Sage.

Robertson, R. and H. Khondker (1997) 'Discourses of Globalization: Preliminary Considerations', International Sociology, 13(1).

Rosamond, B. (2003) 'Babylon and On? Globalization and International Political Economy', Review of International Political Economy, 10(4).

Rose, N. (1993) 'Government, Authority and Expertise in Advanced Liberalism', Economy and Society, 22(3), August.

Rose, N. (1996) 'The Death of the Social? Refiguring the Territory of Government', Economy and Society, 25(3), August.

Saunders, P. (2001) 'Centenary Article - Household Income and Its Distribution', Australia Now, Australian Bureau of Statistics (http://www.abs.gov.au/ausstats).

Saunders, P. (2003) 'Examining Recent Changes in Income Distribution in Australia', Social Policy Research Centre Discussion Paper No. 130.

Shanahan, D. (1997) 'Strength, Not Size, Howard's Way', Australian, 6 May.

Sklair, L. (1997) 'Who Are the Globalisers?', Journal of Australian Political Economy, 38.

Smeeding, T. (2002) 'Global Inequality and the Rich Countries of the G20' in D. Gruen, T. O'Brien and J. Lawson (eds), Globalisation, Living Standards and Inequality: Recent Progress and Continuing Challenges, Canberra, Reserve Bank of Australia and Australian Treasury.

Stretton, H. (1987) Political Essays, Melbourne, Georgian House.

Wallace, C. (1994) 'Time to Get a Handle on How Collective Bargaining Works', Australian Financial Review, 21 December.

Wallace, C. (1995) 'The Big Picture', Australian Financial Review Magazine, December.

Walsh, C. (1991) 'The National Economy and Management Strategies' in B. Galligan and G. Singleton (eds), Business and Government Under Labor, Melbourne, Longman Cheshire. 
Warhust, J. and J. Stewart (1989) 'Manufacturing Industry Policies', in Brian Head and Alan Patience (eds), From Fraser to Hawke: Australian Public Policy in the 1980s, Melbourne, Longman Cheshire.

Watson, M. and C. Hay (2003) 'The Discourse of Globalisation and the Logic of No Alternative: Rendering the Contingent Necessary in the Political Economy of New Labour', Policy and Politics, 31(3).

Whitwell, G. (1993) 'Economic Ideas and Economic Policy: The Rise of Economic Rationalism in Australia', Australian Economic History Review, 33(2).

Youngs, G. (1996) 'Dangers of Discourse: The Case of Globalization' in E. Kofman and G. Youngs (eds), Globalization: Theory and Practice, London, Pinter.

\section{Footnotes}

1 The term rhetoric is used, following McKloskey (1994: xiii), in the Aristotelian sense of using all means of persuasion, rather than the Platonic sense, which implies a concept of "mere rhetoric" implying something opposed to reality or fact. McKloskey argues that rhetoric covers all attempts to explain, including scientific knowledge. For further explication of rhetoric beyond conceptions of "mere rhetoric" see Billig (1989). 